\title{
炭化水素系イオン交換膜とその応用例
}

\author{
田中伸幸 \\ 株式会社アストム 技術部 開発グループ \\ テ 745-8648 山口県周南市御影町 1-1
}

\section{Hydrocarbon-type Ion Exchange Membrane and Its Applications}

\author{
Nobuyuki Tanaka \\ ASTOM CORPORATION, Technical Division, Research \& Development Department, \\ 1-1, Mikage-cho, Shunan-city, Yamaguchi 745-8648, Japan
}

In Japan, hydro-carbon type ion exchange membranes have been developed to produce table salt by electro-dialytic concentration of seawater. Ion exchange membranes have been applying to many industrial fields such as water treatment, food industry, medical supplies, acid recovery from pickling solution and wastewater treatment etc.

This paper describes the characteristics of our ion exchange membranes and applications of our products with our membranes.

Key words : Ion exchange membrane / Electrodialysis / Desalination / Anti-organic fouling membrane / Diffusiondialysis

\section{1. はじめに}

電気透析に用いられる炭化水素系イオン交換膜は, 1950 年に合成高分子による最初の膜が発表された ${ }^{11}$ が，国内でもこの頃より研究が開始され，1960年代 に世界初の食塩製造プラントが操業を開始して以来, イオン交換膜及び電気透析技術は製塩とともに発展 してきた. その後, かん水脱塩等水処理への応用や 有機物と塩分の分離能が高いという特徴から, Fig. 1 に示すように, 食品分野, 化学分野, 環境分野など, 現在ではさまざまな分野で利用されている.

株式会社アストムは，（株）トクヤマと旭化成ケミ カルズ (株) の炭化水素系イオン交換膜の製造合弁会 社として 1995年にスタートし，2004年に営業および 技術開発も一体となり，炭化水素系イオン交換膜及 びそれを組み込んだ透析装置の応用展開に取り組ん

Tel: 0834-34-2333

Fax: 0834-33-3679

E-mail: n.tanaka@astom-corp.jp
でいる，炭化水素系イオン交換膜には陽イオン（カ チオン）選択透過性を有するカチオン交換膜と陰イ オン（アニオン）選択透過性を有するアニオン交換 膜, アニオン層とカチオン層を張り合わせた構造を 持つバイポーラ膜, などがある.

本稿では, 炭化水素系イオン交換膜, 電気透析シ ステムの特徵と, 最近のトピックスを含めその応用 例について紹介する。

\section{2. 炭化水素系イオン交換膜とその特徵}

\section{1 カチオン交換膜とアニオン交換膜}

イオン交換膜に必要とされている性能は, 高いイ オン選択透過性, 低い電気抵抗, 実用に耐えうる機 械的強度, 寸法安定性等であり, これらの性能を満 足したものをこれまで上市してきた. Table 1 に弊社 が販売している代表的なイオン交換膜, ネオセプタ の特徵, 応用例について示す.これらの膜を使い分 けることによって, 様々な用途に応用している. そ の他の特殊なイオン交換膜としては, バイポーラ膜, 


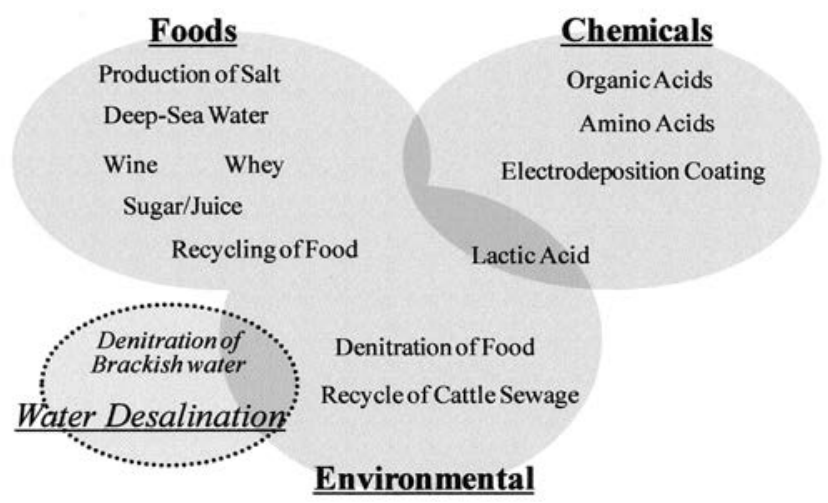

Fig. 1 Applications of electrodialysis process with a hydro-carbon type ion exchange membrane.

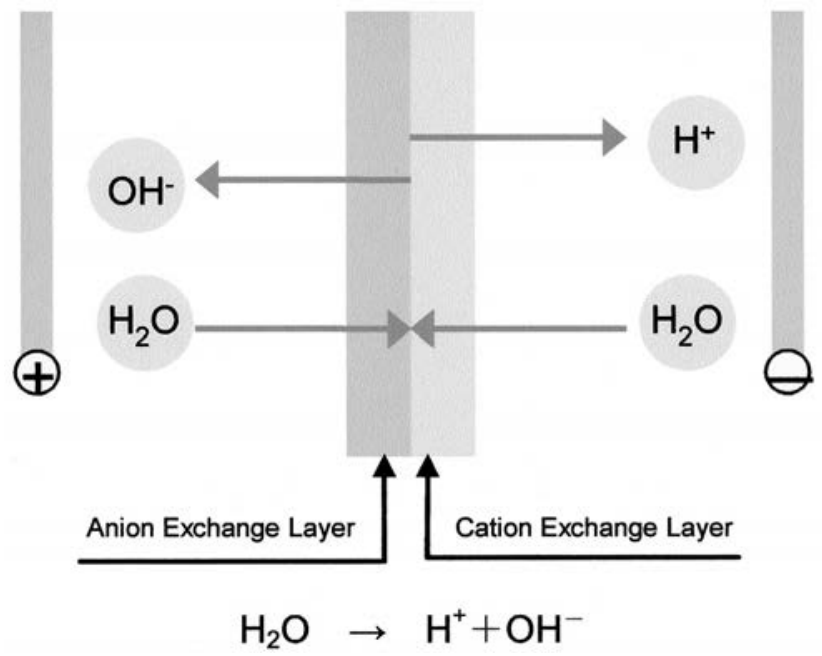

Fig. 2 Bipolar membrane.

耐有機污染膜，EDコア等があり，これらについては 後述する.

\section{2 バイポーラ膜と電気透析モデル}

バイポーラ膜はアニオン交換層, カチオン交換層 を張り合わせた構造を持つイオン交換膜である.こ の膜に, 水の理論分解電圧 $0.83 \mathrm{~V}$ 以上を印加すると Fig. 2のように水を $\mathrm{H}^{+}$と $\mathrm{OH}^{-}$に分解することがで きる.

Fig. 3のように電気透析装置にバイポーラ膜, アニ オン交換膜，カチオン交換膜をセットし液を供給す ると, 矢印のようなイオンの移動が起こり, $\mathrm{Na}_{2} \mathrm{SO}_{4}$ から $\mathrm{H}_{2} \mathrm{SO}_{4}$ と $\mathrm{NaOH}$ が生成する. 反応式は以下のと おりで, 中和の逆の反応が進行する.

$\mathrm{Na}_{2} \mathrm{SO}_{4}+2 \mathrm{H}_{2} \mathrm{O} \rightarrow 2 \mathrm{NaOH}+\mathrm{H}_{2} \mathrm{SO}_{4}$

バイポーラ膜の主な実用例として, 有機酸塩から 有機酸の生成が挙げられる。でんぷんや糖蜜を原料 とし, 菌・かびを作用させて有機酸を製造する場合, 従来法では石灰乳で中和し有機酸のカルシウム塩を
Table 1 Feature and application of ion exchange membrane

\begin{tabular}{ccc}
\hline Grade & Feature & Application (example) \\
\hline Cation exchange membrane & Standard & $\begin{array}{c}\text { Concentration of inorganics } \\
\text { Purification of organics }\end{array}$ \\
CMX & High chemical resistance & Alkali removal \\
CMB & Mono-cation permselective & Deacidification of metal solution \\
CIMS & Production of table salt \\
\hline Anion exchange membrane & Concentration of inorganics \\
\hline AMX & Standard & Purification of organics \\
AHA & High chemical resistance & Alkali removal \\
\hline ACM & Proton blocking & Acid concentration \\
\hline ACS & Mono-anion permselective & Nitrate removal from ground water \\
\hline
\end{tabular}

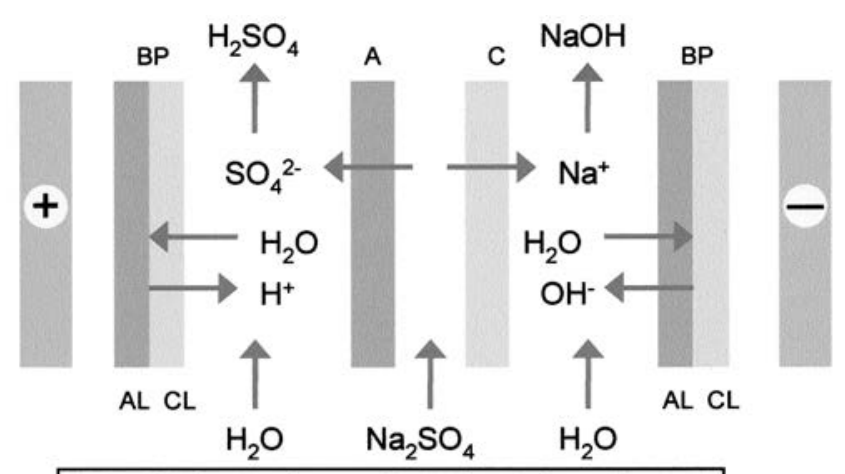

BP: Bipolar Membrane, AL: Anion Exchange Layer, CL : Cation Exchange Layer, A : Anion Exchange Membrane, C : Cation Exchange Membrane

Fig. 3 Bipolar membrane electrodialysis.

生成させ, 熱水に溶解・再結晶を行った後, 硫酸を 添加して遊離酸を得ているのだが, 副産物として大 量の石亳が生成するという久点がある. バイポーラ 膜法による有機酸の製造プロセスは, Fig. 4 に示すよ うに発酵法により生成した有機酸塩を電気透析によ り濃縮し, バイポーラ膜電気透析により有機酸へ変 換する。この方法はプロセスが簡単で, 副生する $\mathrm{NaOH}$ も再利用でき, 廃棄物も少なく, ランニング コストも安くなるといったメリットがある。また， バイポーラ電気透析装置を用いた別の応用例として, 工場から排出される無機塩をこの装置で酸とアルカ リに変換することにより, 工場廃棄物大幅削減と, 酸, アルカリの再利用という 2 重のメリットが生ま れる。

\section{3. 電気透析の応用例}

弊社では Figs. 5, 6に示すように卓上型実験用から 


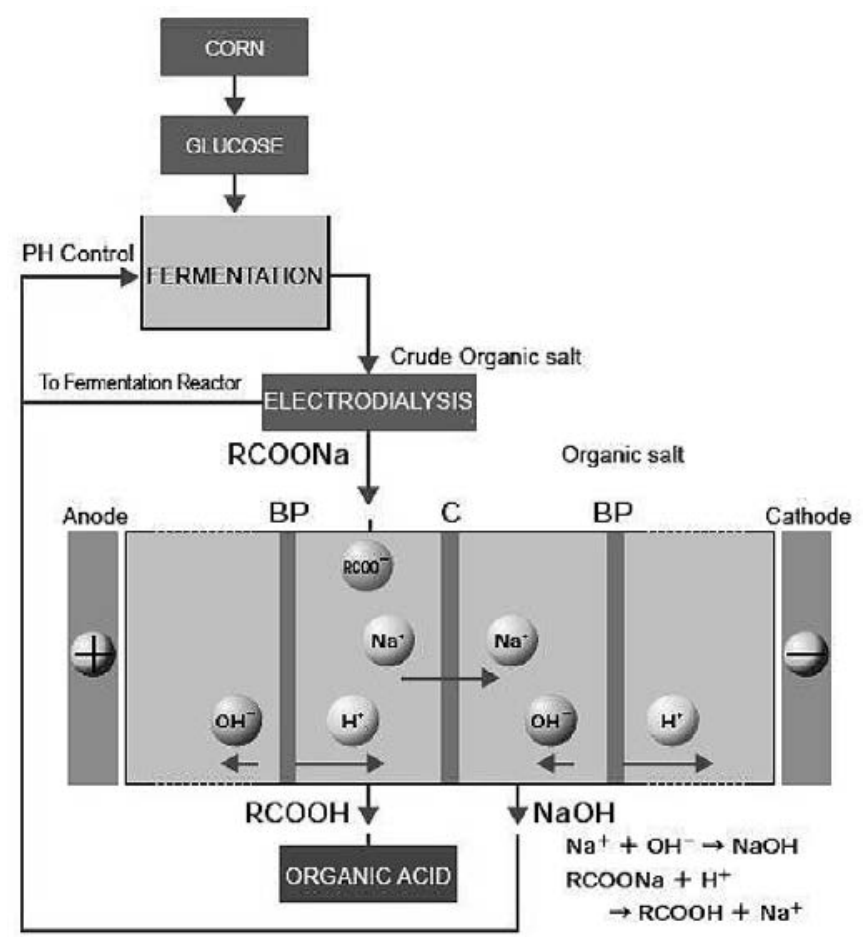

Fig. 4 Flow chart of organic acid production.

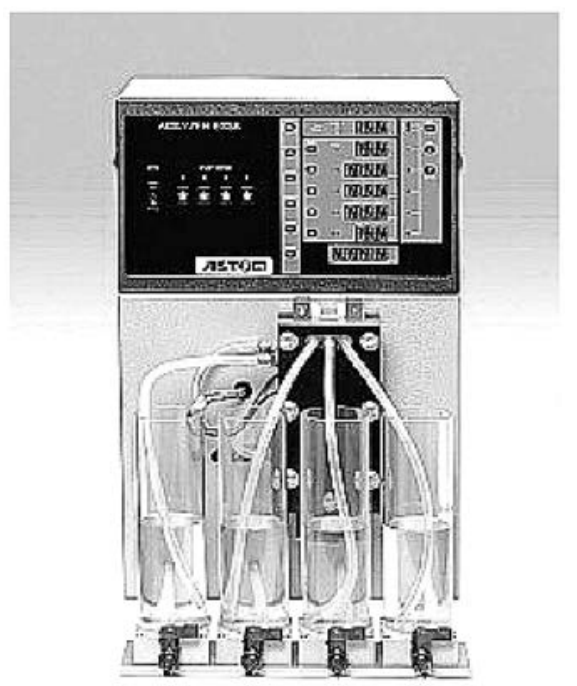

Fig. 5 Acilyzer EX3B, small-scale electrodialyzer.

大型プラントまで用途に応じてさまざまな大きさの 装置を扱っている．ユーザー様と弊社が一緒になっ て実験や技術開発を行うことによって，電気透析技 術の利用範囲は広がりつつある。ここでは, 電気透 析技術の応用例について紹介したい.

\section{1 奨油の脱塩}

まず，奨油の脱塩について説明する．近年の健康 志向により, 奨油についても食塩含有量は減少傾向 にある. 最初の材料段階から塩分を抑えることで減 塩奨油ができそうであるが，塩分濃度が低いと醸造

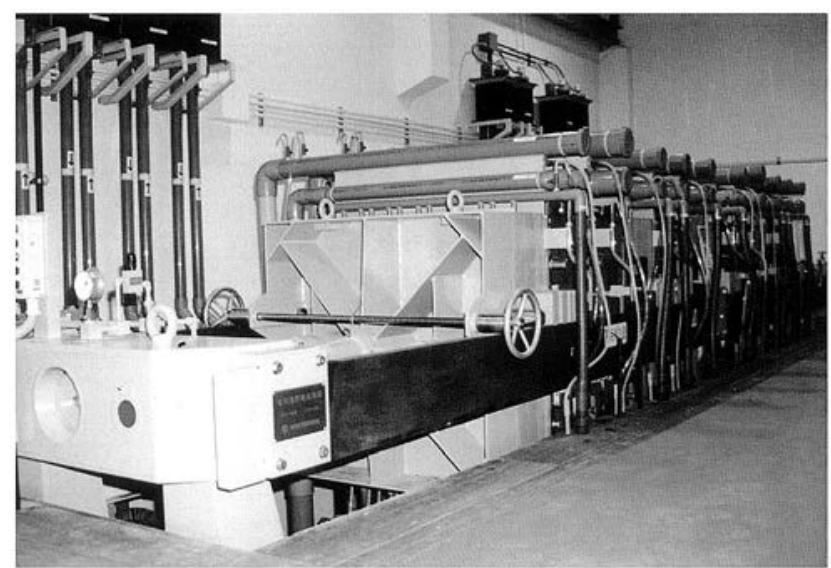

Fig. 6 Large scale electrodialyzer.

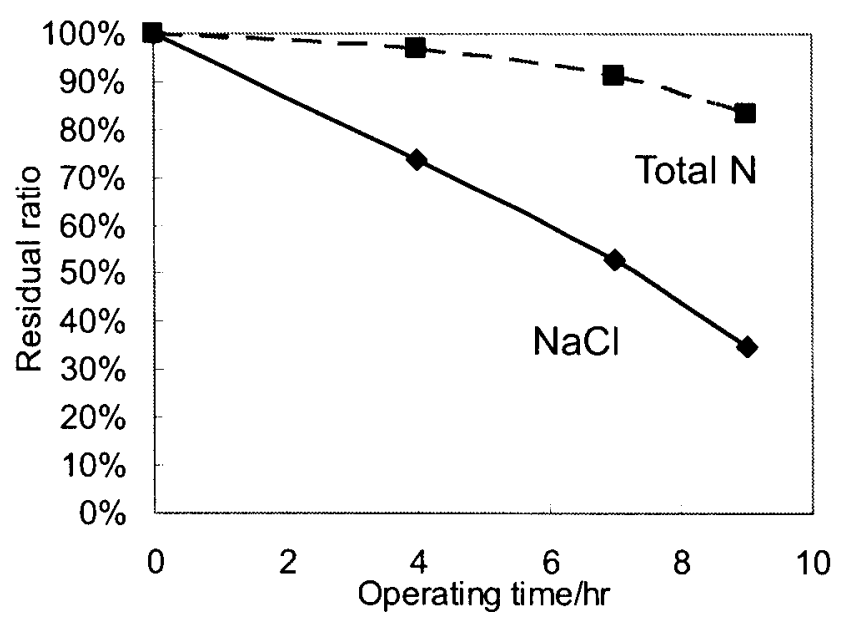

Fig. 7 Desalination of soy source.

中に腐敗してしまうため, 醸造後に塩分濃度を下げ る必要があり, それに電気透析法が用いられている.

電気透析による酱油の脱塩例を Fig. 7 に示す. Total Nはアミノ酸など奨油のうまみ成分, こく等で あり，それらを損なうことなく塩分のみを低減する ことが可能であることが分かる，さらに，通電時間 を調整することによって塩分を自在に調整できる.

\section{2 耐有機污染性に優れたイオン交換膜}

脱塩液にマイナス荷電を有した分子量の大きな有 機アニオン（例：界面活性剤, 一部の日持ち向上剂） を含んでいる場合，この液を電気透析処理すると， アニオン交換膜の表面にマイナス荷電の有機物が堆 積し, 電圧上昇を引き起こす可能性がある. 当社は この有機污染を防ぐため, 耐有機污染性に優れたア ニオン交換膜の開発に成功し, 2007 年 3 月より販売 を開始した。このアニオン交換膜には, 膜表面に薄 い反対荷電層を形成することで, 耐有機污染性を実 現している. 


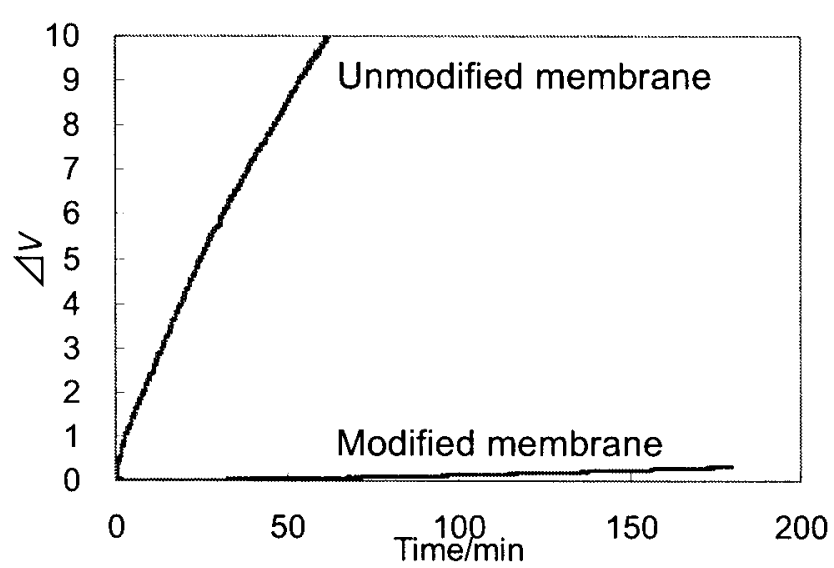

Fig. 8 Organic fouling properties of membranes.

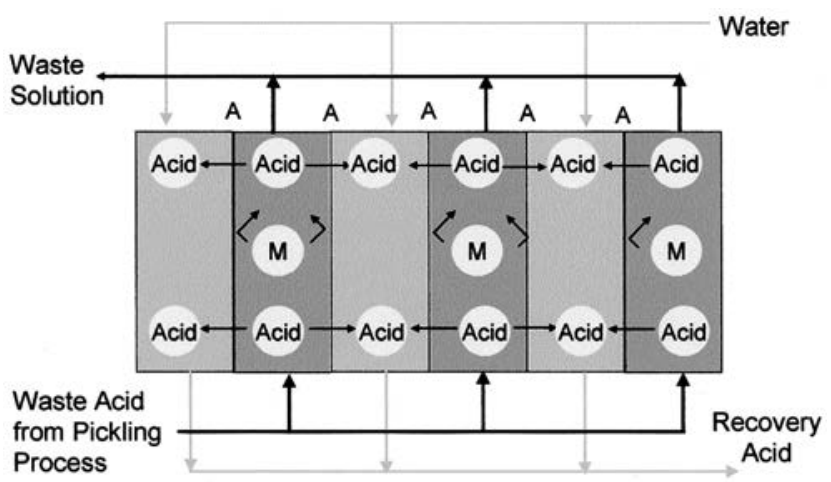

Fig. 9 Principle of diffusiondialysis.

界面活性剂の一種であるドデシルベンゼンスルホ ン酸ナトリウム（DBS）を使った有機污染性の実験 結果を Fig. 8に示す．表面反対荷電層を付与した膜は 付与しない膜と比較して大幅に電圧上昇が抑えられ ており，このことは有機污染が大幅に改善されてい ることを示す。この新膜はすでに梅調味液脱塩に導 入されており, 洗浄頻度が大幅に改善されたという 実績がある.

\section{3 拡散透析 (DD)}

弊社のアニオン交換膜ラインナップに AFNがある が，これは拡散透析用として用いられている。拡散 透析法とは，アニオン交換膜を挟んでその両側の液 の濃度差を利用する酸の回収方法である（Fig. 9).

金属の酸洗処理を続けると酸洗浴中の有効酸濃度 が低下し，また溶解している金属塩濃度が増加する ことにより，時間と共に酸洗効果が低下する．酸回 収用拡散透析装置は有効酸（図中 Acid）と溶解金属 （図中 M）の分離を連続的に行い，酸洗浴の濃度を一 定にコントロールする. また回収した有効酸は酸洗 工程に戻し再使用される。図中の A $\mathrm{AFN}$ である. 拡散透析はイオンの移動に電気を使わないため, ラ
Table 2 Application example of EDR

\begin{tabular}{cccc}
\hline & Unit & $\begin{array}{c}\text { Underground } \\
\text { Water }\end{array}$ & $\begin{array}{c}\text { Product } \\
\text { Water }\end{array}$ \\
\hline Sodium Ion $(\mathrm{Na})$ & $\mathrm{mg} / \mathrm{L}$ & 34 & 24 \\
\hline Chloride Ion $(\mathrm{Cl})$ & $\mathrm{mg} / \mathrm{L}$ & 56 & 11 \\
\hline Total Hardness & $\mathrm{mg} / \mathrm{L}$ & 320 & 56 \\
\hline Nitrate Ion & $\mathrm{mg} / \mathrm{L}$ & 6.1 & 1.8 \\
\hline Electric Conductivity & $\mu \mathrm{S} / \mathrm{cm}$ & 750 & 220 \\
\hline Power Consumption & $\mathrm{kWh} / \mathrm{m}^{3}$ & - & 0.3 \\
\hline
\end{tabular}

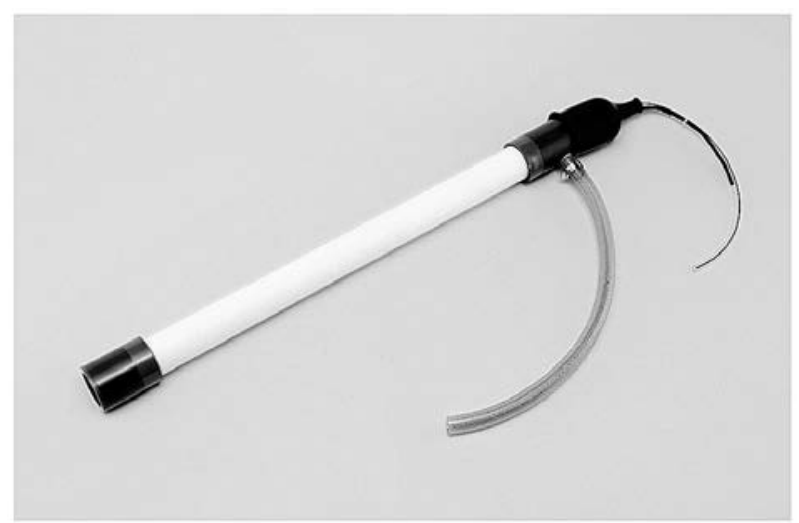

Fig. 10 Tubular ion exchange membrane (EDCORE).

ンニングコストが電気透析より抑えられるメリット がある.

\section{4 極性転換方式電気透析（EDR）}

EDR とは, 通常の電気透析分離技術に加え, 極性 を定期的に切り替えることにより，イオン交換膜表 面に堆積するスケール付着を抑制し, 経済性を高め たものである. 地下水の硬度成分除去, 硝酸性窒素 除去などに利用されている。

EDRの応用例について説明する．地下水の硬度・ 硝酸性窒素除去を目的として, 弊社 EDR装置を使っ て水処理を行った. 処理方法は, まずフィルターに 通した後EDRを用いた. Table 2 に示すように原水の

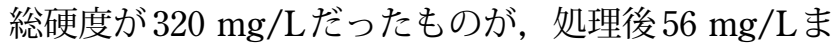
で減少した。

\subsection{ED コア}

これまでは平膜のイオン交換膜を紹介してきたが, 継ぎ目のない滑らかな表面の管状イオン交換膜を使 用した丸隔離膜電極装置であるイーディーコア （Fig. 10）について紹介する. この膜の特徵として, 長時間使用しても污染がほとんどない, 膜の破れ, しわの発生の心配がない, 透水性が皆無であること 
が挙げられる.このことから自動車, 建材, 家電等 の電着塗装及び脱塩・濃縮等に利用されている.

\section{6 その他の電気透析応用技術}

弊社のイオン交換膜を用いた技術は本稿で紹介し た技術以外にもさまざまな技術がある．ここでは最 近確立されつつある電気透析技術について簡単に紹 介する.

バイポーラ膜はこれまで高温領域での使用は, 膜 の劣化を招くため推奨していなかったが, 電力原単 位が高温の方が低いため, 現在耐熱性のバイポーラ 膜の開発を進めており，現在ユーザー評価段階に入 っている.

さらに, 鉄鋼業界からの要望で, ステンレス洗浄 廃液から遊離酸のみならず硝酸, フッ酸の全酸回収 が必要とされており, 電気透析と溶媒抽出の組み合 わせによりそれが実現できるため，提案を行って いる.

\section{4. おわりに}

イオン交換膜は身近なところで使用されており， イオン交換膜技術の裾野を広げつつある. 今後も顧 客のニーズにマッチした膜を開発し，各産業分野の さらなる発展に寄与できる技術を提供していきたい.

\section{文献}

1) Juda W, McRae MA :J. Am. Chem.Soc., 72 1044 (1950)

(Received 10 December 2009;

Accepted 5 February 2010) 